Volume 1 Issue 1, January-June 2020: PP: 1-14

Faculty of Law, Universitas Lampung, Bandar Lampung, Indonesia. http://jurnal.fh.unila.ac.id/index.php/constitutionale

P-ISSN: $2723-2492$

E-ISSN: $2745-9322$

\title{
Kekuasaan Legislasi Dewan Perwakilan Rakyat Pasca Amandemen Undang-Undang Dasar Negara Republik Indonesia Tahun 1945
}

\section{The Legislative Power of the House of Representatives after the Amendment to the 1945 Constitution of the Republic of Indonesia}

\author{
Anis Musana \\ anismusana94@gmail.com \\ Fakultas Hukum Universitas Lampung
}

Submitted: Mar 11, 2020; Reviewed: Apr 2, 2020; Accepted: Apr 23, 2020

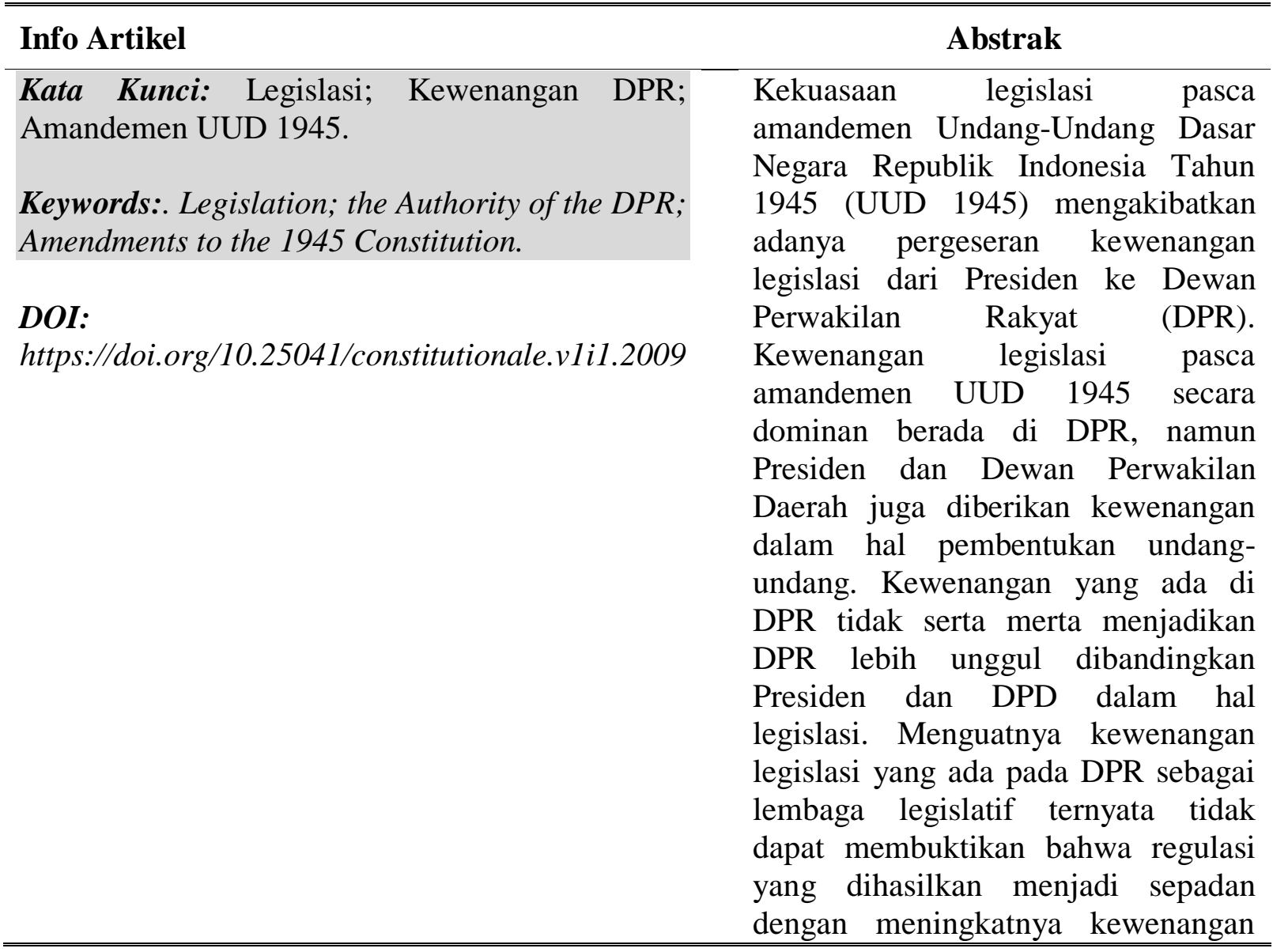


yang didapatkan pasca amandemen UUD 1945. Kenyataannya, regulasi yang berasal dari Presiden dan DPD sebagai lembaga eksekutif terlihat lebih aktif dibandingkan dengan regulasi yang berasal dari DPR. Penelitian ini bertujuan untuk menganalisis dan memetakan secara menyeluruh mengenai kekuasaan legislasi DPR serta kewenangan legislasi yang dimiliki oleh Presiden dan DPD dikarenakan pasca amandemen ketiga lembaga negara tersebut memiliki kewenangan legislasi, jika hal tersebut terjadi akan berpotensi mengurangi kekuasaan legislasi yang dimiliki DPR. Jenis penelitian yang digunakan adalah jenis penelitian normatif dengan pendekatan Normatif-Analistis yang menggunakan sumber data sekunder dengan bahan hukum primer, sekunder, dan tersier. Hasil penelitian menunjukan jika kekuasaan legislasi DPR pasca amandemen UUD 1945 tidak menjadikan DPR memiliki kewenangan kuat dalam proses legislasi, justru produk legislasi dari Presiden dan DPD lebih aktif daripada DPR.

Abstract
The legislative power after the
amendment of the 1945 Constitution
of the Republic of Indonesia (UUD
1945) resulted in a shift in legislative
authority from the President to the
House of Representatives (DPR). The
legislative authority after the
amendment of the 1945 Constitution
predominantly rests with the DPR,
however, the President and the
Regional Representatives Council are
also given the authority to form laws.
The powers that be in the DPR do not
necessarily make the DPR superior to
the President and DPD in terms of
legislation. It turns out that the
strengthening of the legislative power


that is in the DPR as a legislative body cannot prove that the resulting regulations are commensurate with the increased authority obtained after the amendments to the 1945 Constitution. In fact, regulations originating from the President and DPD as executive bodies appear to be more active than those that originate. from the DPR. This study aims to thoroughly analyze and map the legislative power of the DPR as well as the legislative power possessed by the President and DPD because after the amendment the three state institutions have legislative powers, if this happens it will have the potential to reduce the legislative power possessed by the $D P R$. The type of research used is a type of normative research with a Normative-Analytical approach that uses secondary data sources with primary, secondary, and tertiary legal materials.

\section{A. Pendahuluan}

Lembaga negara mampu dibedakan dari perkataan kelompok atau lembaga swasta, lembaga masyarakat, atau yang biasa disebut Organisasi Non Pemerintahan yang dalam bahasa Inggris disebut Non-Government Organization atau Non-Govermental Organizations (NGO). ${ }^{1}$ Maka, lembaga apa pun yang dibentuk bukan sebagai lembaga masyarakat dapat kita disebut sebagai lembaga negara. Lembaga negara itu bisa berada dalam ranah legislatif, eksekutif, dan yudikatif, atau yang bersifat campuran. ${ }^{2}$ Menurut Montesquieu ${ }^{3}$, dalam bukunya “L'Esprit des Lois" (1748), yang mengikuti jalan pikiran John Locke, membagi kekuasaan dalam tiga cabang, yakni kekuasaan legislatif sebagai pembentuk undang-undang, kekuasaan eksekutif yang melaksanakan dan kekuasaan untuk menghakimi atau yudikatif. ${ }^{4}$ Dari klarifikasi Montesquieu inilah dikenal pembagian kekuasaan negara modern dalam tiga fungsi, yaitu legislatif (the legislative function), eksekutif (the executive or administrarive function), dan yudisial (the judicial function). ${ }^{5}$ Istilah pemisahan kekuasaan dalam Bahasa Indonesia merupakan terjemahan perkataan separation of power berdasarkan teori trias politica atau tiga fungsi kekuasaan dalam pandangan Montesquieu, harus dibedakan dan

\footnotetext{
${ }^{1}$ Retno Mawarini Sukmariningsih, "Penataan Lembaga Negara Mandiri Dalam Struktur Ketatanegaraan Indonesia," Mimbar Hukum - Fakultas Hukum Universitas Gadjah Mada 26, no. 2 (2014): 194-204, https://doi.org/10.22146/jmh.16039.

2 Jimly Asshiddiqie, 2006, Perkembangan dan Konsolidasi Lembaga Negara Pasca Reformasi, Jakarta: Sekretariat Jenderal dan Kepaniteraan Mahkamah Konstitusi Republik Indonesia, hlm. 30-31.

${ }^{3}$ Nama lengkap Montesquieu yang sebenarnya adalah Charles de Secondat, Bron de La Brede et de Montesquieu.

${ }^{4}$ Jimly Asshiddiqie, 2014, Pengantar Ilmu Hukum Tata Negara, Jakarta: Rajawali Pers, hlm. 283.

5 O. Hood Phillips, Paul Jackson, and Patricia leopold, 2001, Constitutional and Administrative Law, London: Sweet \& Maxwell, hlm. 10-11.
} 
dipisahkan secara struktural dalam organ-organ yang tidak saling mencampuri urusan masingmasing. ${ }^{6}$ Banyak sekali pro dan kontra yang timbul di kalangan para sarjana mengenai pandangan Montesquieu di lapangan ilmu politik dan hukum. ${ }^{7}$ Dengan menyadari banyaknya kritik terhadap teori trias politica Montesquieu, para ahli hukum di Indonesia acap kali menarik kesimpulan seakan-akan istilah pemisahan kekuasaan (separation of power) yang dipakai oleh Montesquieu itu sendiri tidak dapat dipergunakan. ${ }^{8}$ Kesimpulan demikian dikarenakan penggunaan istilah pemisah kekuasaan itu biasanya diidentikan dengan teori trias politica Montesquieu, dan seolah-olah istilah pemisahan kekuasaan itu hanya dipakai oleh Montesquieu. ${ }^{9}$ Sejatinya, istilah pemisahan kekuasaan itu sendiri merupakan konsep yang bersifat umum, seperti halnya konsep pembagian kekuasaan juga dipakai oleh banyak sarjana dengan pengertian-pengertian yang berbeda-beda satu dengan yang lain. ${ }^{10}$

Konsep bernegara merupakan awalan dari mengatur kehidupan bersama. Kewenangan untuk menetapkan peraturan itu harus diberikan kepada lembaga perwakilan rakyat atau lembaga legislatif. Berdasarkan sistem Undang-Undang Dasar Negara Republik Indonesia Tahun 1945, undang-undang yang dibentuk oleh Dewan Perwakilan Rakyat atas persetujuan bersama dengan Presiden. ${ }^{11}$ UUD 1945 sendiri telah mengalami perubahan sebanyak 4 (empat) kali. Perubahan pertama terjadi tahun 1999, perubahan kedua terjadi tahun 2000, perubahan ketiga terjadi pada 2001, dan perubahan keempat terjadi pada 2002. Beberapa perubahan tesebut terjadi dikarenakan suatu keadaan genting baik dari lembaga negara maupun masyarakat Indonesia dan juga terdapat isi peraturan yang mesti dirubah sehingga membuat pemerintah Indonesia bertindak untuk melakukan perubahan terhadap UUD Negara Republik Indonesia 1945. ${ }^{12}$ Perubahan terhadap konstitusi turut merubah seluruh tatanan dan penyelenggaraan lembaga perwakilan di suatu negara. ${ }^{13}$ Namun setelah UUD 1945 mengalami empat kali perubahan, dapat dikatakan jika sistem konstitusi telah menganut doktrin pemisahan itu secara nyata. ${ }^{14}$ Terutama pada amandemen pertama, amandemen kedua, dan amandemen ketiga mengenai kekuasan legislasi. Pada perubahan-perubahan tersebut, jika ditelaah menimbulkan kesimpulan yang membingungkan mengenai keberadaan kewenangan legislasi tersebut. ${ }^{15}$ Sebelum amandemen UUD 1945, kekuasaan legislasi dipegang oleh Presiden. Kekuasaan legislasi yang dominan pada Presiden tersebut seiring waktu mengalami perubahan setelah munculnya Maklumat Wakil Presiden Nomor X pada tanggal 16 Oktober tahun $1945 .{ }^{16}$ Presiden tidak lagi memegang kekuasaan legislasi sendiri namun juga ada Komite Nasional Indonesia Pusat yang juga ikut menjalankan kekuasaan legislatif. Perubahan

\footnotetext{
${ }^{6}$ Jimly sshiddiqie, 2014, Pengantar Ilmu Hukum Tata Negara, Jakarta: Rajawali Pers, hlm. 285.

${ }^{7}$ Lihat misalnya ulasan G.H. Sabine mengenai kontroversi ini dalam A History of Political Theory, (New York: Holt, Rinehart and Winston, 1961), hlm. 559; lihat juga John Alder and Peter English, Constitutional and Administrative Law, (London: Macmillan, 1989), hlm. 53-54

${ }^{8}$ Zulfan Zulfan, "Analisis Pengaturan Dan Praktik Pemisahan Kekuasaan Sistem Pemerintahan Presidensial Berdasarkan Konstitusi," Jurnal Media Hukum 25, no. 1 (2018): 60-67, https://doi.org/10.18196/jmh.2018.0102.60-67.

${ }^{9}$ Efi Yulistyowati, Endah Pujiastuti, and Tri Mulyani, "Penerapan Konsep Trias Politica Dalam Sistem Pemerintahan Republik Indonesia: Studi Komparatif Atas Undang-Undang Dasar Tahun 1945 Sebelum Dan Sesudah Amandemen," Jurnal Dinamika Sosial Budaya 18, no. 2 (2017): 328-38, https://doi.org/10.26623/jdsb.v18i2.580.

${ }^{10}$ Jimly Asshiddiqie, 2014, Pengantar Ilmu Hukum Tata Negara, Jakarta: Rajawali Pers, hlm. 287.

${ }^{11}$ Rika Marlina, "Summary For Policymakers," in Climate Change 2013 - The Physical Science Basis, ed. Intergovernmental Panel on Climate Change, vol. 1 (Cambridge: Cambridge University Press, 2018), 1-30, https://doi.org/10.1017/CBO9781107415324.004.

12 Martha Pigome, "Implementasi Prinsip Demokrasi Dan Nomokrasi Dalam Struktur Ketatanegaraan Ri Pasca Amandemen Uud 1945," Jurnal Dinamika Hukum 11, no. 2 (2011): 335-48, https://doi.org/10.20884/1.jdh.2011.11.2.191.

13 James Reinaldo Rumpia, 2016, Dinamika Ketatanegaraan Lembaga Perwakilan di Indonesia (skripsi), Fakultas Hukum, Universitas Lampung, hlm. 1.

${ }^{14}$ Lihat Jimly Asshiddiqie, Konstitusi dan Konstitusionalisme Indonesia, Konpress, Jakarta, 2005.

15 Ratnia Solihah and Siti Witianti, "Pelaksanaan Fungsi Legislasi Dewan Perwakilan Rakyat Pasca Pemilu 2014: Permasalahan Dan Upaya Mengatasinya," CosmoGov 2, no. 2 (2016): 291, https://doi.org/10.24198/cosmogov.v2i2.10010.

${ }^{16}$ Saldi Isra, 2010, Pergeseran Fungsi Legislasi: Menguatnya Model Legislasi Parlementer dalam Sistem Presidensial Indonesia, Cet. 1, Jakarta: PT. Rajagrafindo Persada, hlm. 106.
} 
demikian semakin berkembang pasca amandemen UUD 1945 sehingga menempatkan lembaga parlemen yang memegang kekuasaan legislasi. ${ }^{17}$

Perbandingan antara sebelum amandemen dan sesudah amandemen secara singkat bila dilihat pada Pasal 5 ayat (1) sebelum amandemen berbunyi bahwa "Presiden memegang kekuasaan membentuk undang-undang dengan persetujuan Dewan Perwakilan Rakyat", kemudian berubah pada amandemen pertama menjadi Presiden berhak mengajukan Rancangan Undang-Undang kepada Dewan Perwakilan Rakyat. Terhadap pasal tersebut, pada amandemen pertama juga menghasilkan perubahan pada Pasal 20 ayat (1) yang sebelum amandemen berbunyi "Tiap-tiap undang-undang menghendaki persetujuan Dewan Perwakilan Rakyat", kemudian berubah pada amandemen pertama menjadi "Dewan Perwakilan Rakyat memegang kekuasaan membentuk undang-undang". Bunyi dari Pasal 20 ayat (1) tersebut bila diamati memiliki arti perlawanan fungsi legislasi atas Pasal 5 ayat (1) UUD 1945. Berdasarkan hal tersebut, Jimly Asshiddiqie memandang terkait kedua pasal tersebut terjadi pergeseran kekuasaan substantif dalam kekuasaan legislasi atau kekuasaan pembentukan undang-undang dari tangan Presiden ke tangan DPR. ${ }^{18}$

Namun demikian, jika dilihat dari bunyi ayat selanjutnya dari pasal tersebut ternyata Presiden masih memiliki kewenangan legislasi sebagaimana disebutkan pada Pasal 20 ayat (2) berbunyi "setiap rancangan undang-undang dibahas oleh Dewan Perwakilan Rakyat dan Presiden untuk mendapatkan persetujuan bersama". Tidak berhenti di ketentuan dari Pasal 20, Presiden selaku kepala negara memiliki kewenangan mengeluarkan Peraturan Pemerintah Pengganti Undang-Undang (Perppu) sebagaimana disebutkan pada Pasal 22 ayat (1) yang berbunyi "Dalam hal ikhwal kegentingan yang memaksa, Presiden berhak menetapkan peraturan pemerintah pengganti undang-undang". Sedangkan perpu tersebut merupakan sebuah produk hukum yang juga dapat menantang undang-undang hasil produk legislasi dari lembaga legislatif sendiri. Akan tetapi, perpu yang dikeluarkan Presiden akan menjadi sia-sia jika perpu tersebut ternyata ditolak oleh Dewan Perwakilan Rakyat maka perpu tersebut tidak bisa dilanjutkan ke proses selanjutnya. Pasca amandemen UUD 1945 ternyata melahirkan lembaga baru yang memiliki fungsi legislasi yakni Dewan Perwakilan Daerah. Dewan Perwakilan Daerah Republik Indonesia memiliki kewenangan legislasi yaitu dalam hal mengajukan Rancangan Undang-Undang yang terkait dengan kepentingan daerah. memang terlihat miris mengenai kewenangan legislasi Dewan Perwakilan Daerah yang terbatas, padahal jika dilihat lembaga ini memliki potensi yang besar bagi perkembangan daerah. Rumusan masalah dalam penelitian ini adalah bagaimanakah kekuasaam legislasi di Indonesia pasca amandemen Undang-Undang Dasar Negara Republik Indonesia Tahun 1945?

\section{B. Pembahasan}

\section{Kewenangan Legislasi Sebelum Amandemen Uud 1945}

Kewenangan legislasi sebelum amandemen dipegang oleh Presiden dengan persetujuan

Dewan Perwakilan Rakyat. Dewan Perwakilan Rakyat pertama kali dikenal dengan nama Komite Nasional Indonesia Pusat (KNIP). KNIP yang dilantik pada tanggal 29 Agustus $1945^{19}$ ini dibentuk atas dasar ketentuan yang terdapat dalam Pasal IV Aturan Peralihan UUD 1945 yang menyatakan:

\footnotetext{
${ }^{17}$ Syofyan Hadi, "Fungsi Legislasi Dalam Sistem Pemerintahan Presidensil (Studi Perbandingan Indonesia Dan Amerika Serikat)," DiH: Jurnal Ilmu Hukum 9, no. 18 (2013), https://doi.org/10.30996/dih.v9i18.275.

18 Jimly Asshiddiqie, 2006, Perkembangan dan Konsolidasi Lembaga Negara Pasca Reformasi, Jakarta: Sekretariat Jenderal dan Kepaniteraan Mahkamah Konstitusi Republik Indonesia, hlm. 135.

${ }^{19}$ KNIP dengan susunan keanggotaan sebagai berikut: a. Ketua: Mr Kasman Singodimedjo; b. Wakil Ketua: Mr. Sutardjo Kartohadikusumo; c. Wakil Ketua: Mr. J Latuharhary, d. Wakil Ketua: Adam Malik., Miriam Budiarjo, Dasar-Dasar Ilmu Politik, Opcit, hlm. 331.
} 
Sebelum Majelis Permusyawaratan Rakyat, Dewan Perwakilan Rakyat, dan Dewan Pertimbangan Agung dibentuk menurut Undang-Undang Dasar ini (UUD 1945, pen.) segala kekuasaannya dijalankan oleh Presiden dengan bantuan sebuah komite nasional.

Berdasarkan ketentuan tersebut, KNIP dalam hal ini tidak memiliki kedudukan yang sama dengan Presiden, melainkan hanya sebagai lembaga yang membantu Presiden dalam pembentukan undang-undang. Dengan maklumat Wakil Presiden No. X tersebut, maka ketentuan dari Pasal IV Aturan Peralihan UUD 1945 menjadi tidak berlaku lagi atau dicabut. Ketentuan dari maklumat ini juga mengartikan bahwa KNIP memiliki kewenangan legislasi atau ikut membentuk undang-undang bersama-sama dengan Presiden.

Frasa 'bersama-sama tidak ditemukan dalam UUD 1945 sebelum amandemen, namun terdapat dalam penjelasan umum dari UUD 1945 tepatnya pada Pasal 5 ayat (1) yaitu: kecuali executive power, Presiden bersama-sama dengan Dewan Perwakilan Rakyat menjalankan legislative power dalam negara. Walaupun DPR telah memegang kembali kewenangannya untuk ikut serta dalam pembentukan undang-undang, namun kewenangan DPR tersebut masih sangat terbatas dibandingkan dengan kewenangan Presiden dalam pembentukan undangundang. Secara garis besar Presiden menguasai kewenangan legislasi walaupun di dalamnya terdapat DPR. DPR hanya sebatas menyetujui atas rancangan undang-undang yang dibahas bersama Presiden pada masa itu. Selain itu, kewenangan legislasi DPR sebelum amandemen UUD seperti halnya Rancangan Undang-Undang usul dari anggota DPR walaupun telah disetujui DPR tetapi tidak disahkan Presiden, maka Rancangan Undang-Undang tersebut tidak boleh dimajukan lagi. ${ }^{20}$ Presiden diberikan kekuasaan untuk mengesahkan Rancangan Undang-Undang atas usul DPR ataupun tidak mengesahkan dalam arti tidak dapat dimajukan kembali Rancangan Undang-Undang tersebut. Lebih jelas mengenai kewenangan legislasi dari lembaga Presiden dan DPR diterangkan berdasarkan Undang-Undang Dasar Negara Republik Indonesia Tahun 1945, dalam tabel di bawah ini.

Tabel 1.1 Kewenangan legislasi sebelum amandemen UUD 1945

\begin{tabular}{|c|c|c|}
\hline No. & Nama Lembaga & Pasal Terkait \\
\hline 1 & Kewenangan Presiden & $\begin{array}{l}\text { - Pasal } 5 \text { ayat (1): Presiden memegang } \\
\text { kekuasaan membentuk undang-undang } \\
\text { dengan persetujuan Dewan Perwakilan } \\
\text { Rakyat. } \\
\text { - Pasal } 5 \text { ayat (2): Presiden menetapkan } \\
\text { peraturan pemerintah untuk menjalankan } \\
\text { undang-undang sebagaimana mestinya. }\end{array}$ \\
\hline 2 & Kewenangan DPR & $\begin{array}{l}\text { - Pasal } 20 \text { ayat (1): Tiap-tiap undang- } \\
\text { undang menghendaki persetujuan Dewan } \\
\text { Perwakilan Rakyat. } \\
\text { - Pasal } 20 \text { ayat (2): Jika suatu rancangan } \\
\text { undang-undang tidak mendapat } \\
\text { persetujuan Dewan Perwakilan Rakyat, } \\
\text { maka rancangan tadi tidak boleh } \\
\text { dimajukan lagi dalam persidangan Dewan } \\
\text { Perwakilan Rakyat masa itu. } \\
\text { - Pasal 21 ayat (1): Anggota-anggota } \\
\text { Dewan Perwakilan Rakyat berhak } \\
\text { memajukan rancangan undang-undang. }\end{array}$ \\
\hline
\end{tabular}

${ }^{20}$ Herman Herman and Firman Muin, "Sistematisasi Jenis Dan Hierarki Peraturan Perundang-Undangan Di Indonesia," Jurnal Komunikasi Hukum (JKH) 4, no. 2 (2018): 89-101, https://doi.org/10.23887/jkh.v4i2.15445. 


\begin{tabular}{|l|l|}
\hline & $\begin{array}{l}\text { Pasal 21 ayat (2): Jika rancangan itu } \\
\text { meskipun disetujui Dewan Perwakilan } \\
\text { Rakyat, tidak disahkan oleh Presiden } \\
\text { maka rancangan tadi tidak boleh } \\
\text { dimajukan lagi. }\end{array}$ \\
\hline
\end{tabular}

Sumber: UUD 1945 sebelum amandemen.

Kewenangan legislasi sebagaimana diterangkan pada tabel di atas, penulis berpendapat jika sistem yang berlaku sebelum amandemen UUD 1945 adalah executive heavy terutama dalam pembentukan undang-undang. Presiden sebagai lembaga eksekutif kekuasaannya lebih dominan dalam pembentukan undang-undang. Presiden membentuk undang-undang dan kata menyetujui tidak ada pada Presiden dikarenakan Presiden yang memegang kekuasaan utama sedangkan DPR hanya sebatas menyetujui. ${ }^{21}$ Kata menyetujui yang ada pada lembaga DPR memang memiliki sedikit kendali dalam kewenangan legislasi. Rancangan undang-undang yang diajukan harus dengan persetujuan, baik berupa disetujui maupun tidak disetujui. Jika rancangan undang-undang tersebut disetujui DPR maka rancangan undang-undang tersebut maju pada sidang saat itu, sedangkan jika rancangan undang-undang tersebut tidak mendapat persetujuan dari DPR, maka rancangan undang-undang tersebut tidak lagi dimajukan pada sidang Dewan Perwakilan Rakyat pada masa itu. Rancangan undang-undang usul anggota DPR yang disetujui Dewan Perwakilan Rakyat pun tidak akan dimajukan lagi jika tanpa disahkan Presiden terlebih dahulu. ${ }^{22}$ Kewenangan Presiden yang besar ini menandakan bahwa kedudukan DPR dianggap tidak begitu berpengaruh atau mengusik kekuasaan Presiden karena kewenangan kekuasaan membentuk undang-undang DPR sangat terbatas. Dapat dilihat dari ragaan di bawah ini mengenai usul rancangan undang-undang yang terjadi antara Presiden dengan Dewan Perwakilan Rakyat.

\section{Kewenangan Legislasi Pasca Amandemen Uud 1945}

Pasca amandemen UUD 1945, kewenangan legislasi telah mengalami perubahan yang signifikan. -Perubahan kewenangan legislasi terjadi pada lembaga Dewan Perwakilan Rakyat dan Presiden. Tidak berhenti pada lembaga Presiden dan Dewan Perwakilan Rakyat, dalam perubahan amandemen ini melahirkaan lembaga baru yang ikut andil dalam kewenangan legislasi yaitu Dewan Perwakilan Daerah. ${ }^{23}$ Secara spesifik kewenangan legislasi terdapat pada amandemen pertama, amandemen kedua, dan amandemen ketiga.

Tabel 1.2. Perubahan-perubahan kekuasaan legislasi dalam Undang-Undang Dasar Negara Republik Indonesia Tahun 1945, sebelum amandemen, amandemen pertama, amandemen kedua, dan ketiga.

\begin{tabular}{|l|l|r|}
\hline No. & UUD 1945 & Pasal Terkait \\
\hline 1 & Sebelum Amandemen & $\begin{array}{l}\text { Pasal 5 ayat (1): Presiden memegang } \\
\text { kekuasaan membentuk undang-undang }\end{array}$ \\
\hline
\end{tabular}

\footnotetext{
${ }^{21}$ D. Aritonang, "Penerapan Sistem Presidensil Di Indonesia Pasca Amandemen UUD 1945," Mimbar Hukum - Fakultas Hukum Universitas Gadjah Mada 22, no. 2 (2010): 391-407, https://doi.org/10.20303/jmh.v22i2.296.

${ }^{22}$ Hernadi Affandi, "Problematika Fungsi Legislasi Dewan Perwakilan Daerah Dalam Hegemoni Dewan Perwakilan Rakyat," PADJADJARAN Jurnal Ilmu Hukum (Journal of Law) 1, no. 1 (2014): 135-54, https://doi.org/10.22304/pjih.v1n1.a8.

23 Sri Hastuti Puspitasari, "Penyelesaian Sengketa Kewenangan Konstitusional Lembaga Negara Sebagai Salah Satu Kewenangan Mahkamah Konstitusi," JURNAL HUKUM IUS QUIA IUSTUM 21, no. 3 (2014): 402-25, https://doi.org/10.20885/iustum.vol21.iss3.art4.
} 


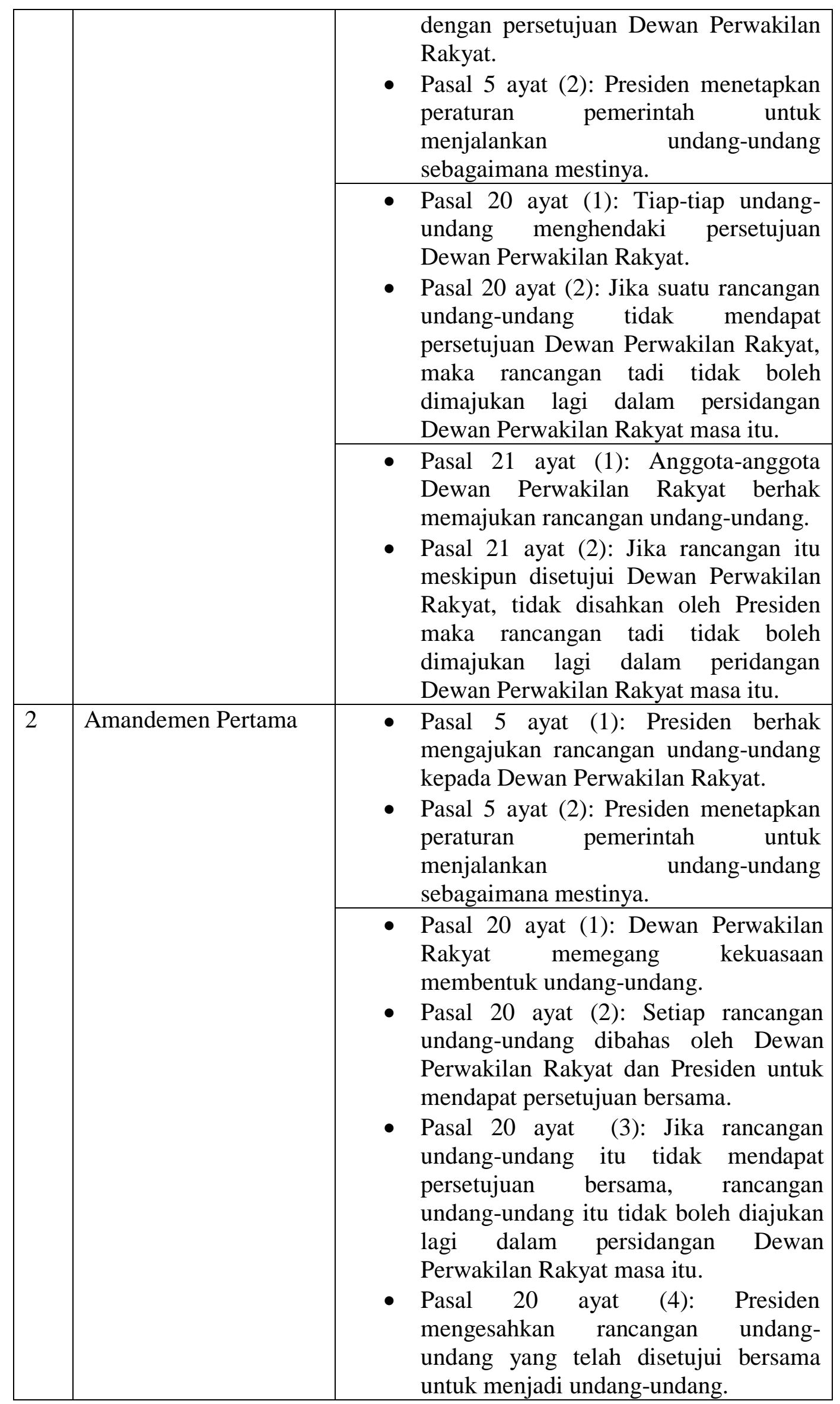




\begin{tabular}{|c|c|c|}
\hline & & $\begin{array}{l}\text { - Pasal 21: Anggota Dewan Perwakilan } \\
\text { Rakyat berhak mengajukan usul } \\
\text { rancangan undang-undang. }\end{array}$ \\
\hline 3 & Amandemen Kedua & $\begin{array}{l}\text { - Pasal } 20 \text { ayat (1): Dewan Perwakilan } \\
\text { Rakyat memegang kekuasaan } \\
\text { membentuk undang-undang. } \\
\text { - Pasal } 20 \text { ayat (2): Setiap rancangan } \\
\text { undang-undang dibahas oleh Dewan } \\
\text { Perwakilan Rakyat dan Presiden untuk } \\
\text { mendapat persetujuan bersama. } \\
\text { - Pasal } 20 \text { ayat (3): Jika rancangan } \\
\text { undang-undang itu tidak mendapat } \\
\text { persetujuan bersama, rancangan } \\
\text { undang-undang itu tidak boleh diajukan } \\
\text { lagi dalam persidangan Dewan } \\
\text { Perwakilan Rakyat masa itu. } \\
\text { - Pasal 20 ayat (4): } \\
\text { mengesahkan rancangan undang- } \\
\text { undang yang telah disetujui bersama } \\
\text { untuk menjadi undang-undang. } \\
\text { Pasal } 20 \text { ayat (5): Dalam hal rancangan } \\
\text { undang-undang yang telah disetujui } \\
\text { bersama tersebut tidak disahkan oleh } \\
\text { Presiden dalam waktu tiga puluh hari } \\
\text { semenjak rancangan undang-undang } \\
\text { tersebut disetujui, rancangan undang- } \\
\text { undang tersebut sah menjadi undang- } \\
\text { undang dan wajib diundangkan. }\end{array}$ \\
\hline 4 & Amandemen Ketiga & $\begin{array}{l}\text { - Pasal 22D ayat (1): Dewan Perwakilan } \\
\text { Daerah dapat mengajukan kepada } \\
\text { Dewan Perwakilan Rakyat rancangan } \\
\text { undang-undang yang berkaitan dengan } \\
\text { otonomi daerah, hubungan pusat dan } \\
\text { daerah, pembentukan dan pemekaran } \\
\text { serta penggabungan daerah, } \\
\text { pengelolaan sumber daya alam dan } \\
\text { sumber daya ekonomi lainnya, serta } \\
\text { yang berkaitan dengan perimbangan } \\
\text { keuangan pusat dan daerah. } \\
\text { Pasal 22D ayat (2): Dewan Perwakilan } \\
\text { Daerah ikut membahas rancangan } \\
\text { undang-undang yang berkaitan dengan } \\
\text { otonomi daerah; hubungan pusat dan } \\
\text { daerah; pembentukan, pemekaran dan } \\
\text { penggabungan daerah; pengelolaan } \\
\text { sumber daya alam, dan sumber daya } \\
\text { ekonomi lainnya serta perimbangan } \\
\text { keuangan pusat dan daerah; serta } \\
\text { memberikan pertimbangan kepada }\end{array}$ \\
\hline
\end{tabular}




\begin{tabular}{|l|l|}
\hline & Dewan Perwakilan Rakyat atas \\
& rancangan undang-undang anggaran \\
& pendapatan dan belanja negara dan \\
& rancangan undang-undang yang \\
& berkaitan dengan pajak, pendidikan, dan \\
& agama.
\end{tabular}

Sumber: UUD 1945 sebelum dan pasca amandemen.

Berdasarkan kewenangan legislasi pada tabel di atas, penulis melihat jika perubahanperubahan yang terjadi dalam kekuasaan legislasi pasca amandemen yakni:

1) Kewenangan Dewan Perwakilan Rakyat begitu meningkat pasca amandemen UndangUndang Dasar Negara Republik Indonesia Tahun 1945. Dewan Perwakilan Rakyat sebelumnya memiliki kewenangan terbatas sebelum amandemen UUD 1945. Kondisi lemahnya kedudukan DPR ini berubah pasca reformasi. Sekarang pasca amandemen, Dewan Perwakilan Rakyat lebih dominan dalam memegang kekuasaan legislasi dibandingkan Presiden apalagi Dewan Perwakilan Daerah. ${ }^{24}$ Misalkan pada Pasal 5 ayat (1) sebelumnya berbunyi bahwa Presiden memegang kekuasaan membentuk undangundang dengan persetujuan Dewan Perwakilan Rakyat, kemudian berubah menjadi Presiden berhak mengajukan rancangan undang-undang kepada Dewan Perwakilan Rakyat. Pasca amandemen UUD 1945, DPR menggeser kewenangan legislasi dari Presiden ke DPR. Selain itu, pasca amandemen anggota-anggota Dewan Perwakilan juga dapat mengajukan rancangan undang-undang tanpa pengesahan Presiden. ${ }^{25}$

2) Pada tahap pengesahan, rancangan undang-undang memasuki tahapan pengesahan oleh Presiden. ${ }^{26}$ Dalam hal ini, Pasal 20 ayat (4) UUD 1945 menyatakan, "Presiden mengesahkan rancangan undang-undang yang telah disetujui bersama untuk menjadi undang-undang". Dibandingkan dengan Pasal 20 ayat (4) UUD 1945, UUD 1945 sebelum perubahan tidak mengatur secara lengkap ketentuan pengesahan rancangan undang-undang. Artinya, sebelum perubahan, pengesahan rancangan undang-undang didasarkan pada bunyi Pasal 20 ayat (2) UUD 1945 menyebutkan, jika rancangan itu meskipun disetujui Dewan Perwakilan Rakyat, tidak disahkan oleh Presiden, maka rancangan tadi tidak boleh dimajukan lagi dalam persidangan Dewan Perwakilan Rakyat masa itu.

3) Akibat dari pergeseran kekuasaan legislasi dari Presiden ke DPR, Presiden pada pasca amandemen memiliki kewenangan legislasi dalam hal pembahasan, persetujuan, dan pengesahan. Namun dalam hal pengesahan rancangan undang-undang oleh Presiden dianggap percuma karena disahkan atau tidak disahkan Presiden, rancangan undangundang akan tetap diundangkan. ${ }^{27}$

4) Walaupun Dewan Perwakilan Daerah memang merupakan lembaga baru yang memiliki kewenangan legislasi, akan tetapi kewenangannya tersebut sangat terbatas yaitu hanya mengusulkan dan membahas rancangan undang-undang terkait kepentingan daerah.

\footnotetext{
${ }^{24}$ Miki Pirmansyah, "Eksistensi Dewan Perwakilan Daerah Dalam Sistem Bikameral Di Indonesia," JURNAL CITA HUKUM

2, no. 1 (2014), https://doi.org/10.15408/jch.v1i1.1461.

${ }^{25}$ Saldi Isra, "Hubungan Presiden Dan DPR," Jurnal Konstitusi 10, no. 3 (2013): 399-416.

${ }^{26}$ Saldi Isra, 2010, Pergeseran Fungsi Legislasi: Menguatnya Model Legislasi Parlementer dalam Sistem Presidensial Indonesia, Cet. 1, Jakarta: PT. Rajagrafindo Persada, hlm. 225.

27 Agus Riswanto, "Strategi Politik-Hukum Meningkatkan Kualitas Kinerja DPR Ri Dalam Produktivitas Legislasi Nasional," JURNAL CITA HUKUM 4, no. 2 (2016), https://doi.org/10.15408/jch.v4i2.4140.
} 


\section{Ragaan 1. Tingkatan DPR, Presiden, dan DPD.}

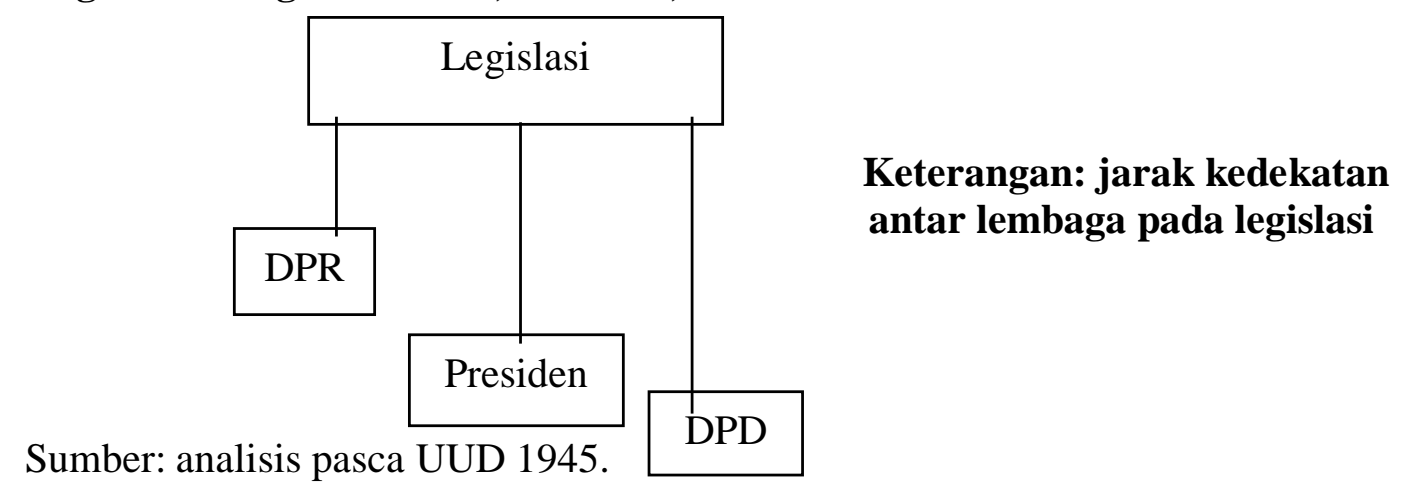

Seperti terlihat pada kerangka di atas, kewenangan membentuk undang-undang pasca amandemen mengalami perubahan. Dari ketiga lembaga tersebut, lembaga yang paling dekat membentuk undang-undang berada di Dewan Perwakilan Rakyat. Kewenangan legislasi yang ada pada DPR berkembang pasca amandemen UUD 1945. DPR berwenang: ${ }^{28}$

a. membentuk undang-undang yang dibahas dengan Presiden untuk mendapat persetujuan bersama;

b. memberikan persetujuan atau tidak memberikan persetujuan terhadap peraturan pemerintah pengganti undang-undang yang diajukan oleh Presiden untuk menjadi undang-undang;

c. membahas rancangan undang-undang yang diajukan oleh Presiden atau DPR;

d. membahas rancangan undang-undang yang diajukan DPD mengenai otonomi daerah, hubungan pusat dan daerah, pembentukan dan pemekaran serta penggabungan daerah, pengelolaan sumber daya alam dan sumber daya ekonomi lainnya, serta pertimbangan keuangan pusat dan daerah;

e. membahas bersama Presiden dengan memperhatikan pertimbangan DPD dan memberikan persetujuan atas rancangan undang-undang tentang APBN yang diajukan oleh Presiden;

f. membahas dan menindaklanjuti hasil pengawasan yang disampaikan oleh DPD atas pelaksanaan undang-undang mengenai otonomi daerah, pembentukan, pemekaran dan penggabungan daerah, hubungan pusat dan daerah, pengelolaan sumber daya alam dan sumber daya ekonomi lainnya, pelaksanaan APBN, pajak, pendidikan, dan agama.

Walaupun Presiden sebagai kepala negara, akan tetapi perannya dalam pembentukan undang-undang tidak sebanding dengan kewenangan yang dimiliki Dewan Perwakilan Rakyat. Kewenangan Presiden lebih rendah dibandingkan Dewan Perwakilan Rakyat. Dewan Perwakilan Daerah juga tingkatannya lebih rendah dibandingkan Dewan Perwakilan Rakyat walaupun kedua lembaga ini termasuk ke dalam lembaga perwakilan, namun posisinya subordinat. ${ }^{29}$ Jauh jika membandingkan dengan Dewan Perwakilan Rakyat, bahkan Dewan Perwakilan Daerah pun kewenangannya lebih rendah dari Presiden. Maka, jika ditingkatkan pada lembaga mana yang memegang kekuasaan legislasi yaitu Dewan Perwakilan Rakyat, Presiden, dan Dewan Perwakilan Daerah.

\footnotetext{
${ }^{28}$ Pasal 71 angka a-f, Undang-Undang Nomor 2 Tahun 2018 tentang Perubahan Kedua Atas Undang-Undang Nomor 17 Tahun 2014 tentang Majelis Permusyawaratan Rakyat, Dewan Perwakilan Rakyat, Dewan Perwakilan Daerah, dan Dewan Perwakilan Rakyat Daerah.

${ }^{29}$ Yadi Supriadi, "Komunikasi Politik DPRD Dalam Meningkatkan Peran Legislasi Di Kota Bandung," Mediator: Jurnal Komunikasi 10, no. 1 (2017): 25-36, https://doi.org/10.29313/mediator.v10i1.2119.
} 
Tabel 1.3. Rancangan Undang-Undang DPR, Pemerintah, DPD Periode 2005-2019.

\begin{tabular}{|c|c|c|c|c|c|c|}
\hline \multirow[t]{2}{*}{ No. } & \multirow[t]{2}{*}{ Tahun } & \multicolumn{4}{|c|}{ Prolegnas (Prioritas, Kumulatif) } & \multirow{2}{*}{$\begin{array}{l}\text { Undang- } \\
\text { Undang }\end{array}$} \\
\hline & & DPR & Pemerintah & DPD & $\begin{array}{l}\text { DPR, } \\
\text { Pemerintah }\end{array}$ & \\
\hline 1 & $2005-2009$ & \multicolumn{4}{|c|}{286} & 191 \\
\hline 2 & 2010 & 120 & 63 & - & 62 & 13 \\
\hline 3 & 2011 & 65 & 47 & - & - & 24 \\
\hline 4 & 2012 & 46 & 23 & - & - & 24 \\
\hline 5 & 2013 & 48 & 27 & - & - & 23 \\
\hline 6 & 2014 & 44 & 24 & 1 & - & 40 \\
\hline 7 & 2015 & 29 & 22 & 1 & - & 13 \\
\hline 8 & 2016 & 33 & 17 & 2 & 1 & 19 \\
\hline 9 & 2017 & 36 & 19 & 3 & - & 18 \\
\hline 10 & 2018 & 31 & 27 & 3 & - & 13 \\
\hline 11 & 2019 & 35 & 16 & 4 & - & 5 \\
\hline & & & Total & & & 383 \\
\hline
\end{tabular}

Sumber: diolah dari berbagai sumber. ${ }^{30}$

Berdasarkan data rancangan undang-undang pada prolegnas di atas, penulis berpendapat bahwa tingkatan kewenangan legislasi yang dimiliki Dewan Perwakilan Rakyat, Presiden, dan Dewan Perwakilan Daerah ternyata berdampak pada kinerja dari lembaga-lembaga tersebut sebagaimana rancangan undang-undang yang masuk dalam prolegnas. Prolegnas prioritas yang berasal dari Dewan Perwakilan Rakyat menghasilkan rancangan undang-undang yang jumlahnya lebih banyak dari pada jumlah rancangan undang-undang hasil Presiden dan Dewan Perwakilan Daerah. Berbeda halnya dengan prolegnas prioritas, terhitung bahwa prolegnas kumulatif terbanyak yaitu dari pemerintah dibandingkan dengan prolegnas kumulatif asal DPR.

Lain halnya dengan usul Rancangan Undang-Undang dari setiap lembaga, regulasi atau undang-undang hasil dari prolegnas tersebut lebih unggul dihasilkan oleh lembaga eksekutif dibandingkan dengan regulasi yang dihasilkan DPR sebagai lembaga legislatif. Contoh regulasi asal Presiden yaitu menghasilkan banya undang-undang hasil dari ratifikasi internasional seperti UU No. 10 Tahun 2018 tentang Pengesahan Persetujuan Kerjasama Pertahanan antara Pemerintah Republik Indonesia dan Pemerintah Kerajaan Arab Saudi (Defense Cooperation Agreement Between The Goverment Of The Republic Of Indonesia and The Goverment Of The Kingdom Of Saudi Arabia), dan lainnya. Berdasarkan data Usulan DPD untuk RUU dalam Prolegnas 2020-2024 juga menerangkan bahwa rancangan undangundang dalam Prolegnas dari Tahun 2005-2019 jumlah total terdapat 78 RUU yang diusulkan oleh DPD dan terhitung juga 28 RUU yang telah disahkan menjadi undang-undang atau regulasi. Jumlah regulasi tersebut salah satu diantaranya adalah Undang-Undang Nomor 32 Tahun 2009 tentang Perlindungan dan Pengelolaan Lingkungan Hidup dan Undang-Undang Nomor 18 Tahun 2013 tentang Pencegahan dan Pemberantasan Perusakan Hutan. Berdasarkan hal tersebut, nyatanya meskipun pasca amandemen terjadi pergeseran kekuasaan dari tangan Presiden ke tangan DPR, akan tetapi Presiden tetap lebih unggul dan lebih aktif dalam legislasi. Melihat kewenangan DPR dan Presiden yang demikian, kewenangan Dewan Perwakilan Daerah begini terkesan dianggap tidak begitu berada. Kondisi demikian mungkin terjadi karena kewenangannya yang sedikit dibandingkan DPR dan Presiden menurut UUD

30 http://www.dpr.go.id/uu/prolegnas-long-lis, diakses pada tanggal 16 Februari 2019, 20:45 WIB., https://jdih.setneg.go.id, diakses pada tanggal 8 Maret 2019, 14:01 WIB., http://peraturan.go.id, diakses pada tanggal 20 Maret 2019, 10:00 WIB. 
1945. ${ }^{31}$ Andai kewenangannya diperluas dalam UUD 1945, bisa saja kinerja Dewan Perwakilan Daerah akan semakin baik lagi terutama dalam hal menghasilkan rancangan undang-undang.

\section{Kesimpulan}

Kekuasaan legislasi Dewan Perwakilan Rakyat pasca amandemen UUD 1945 mengalami perubahan yang cukup signifikan jika melihat kembali pada kewenangan legislasi sebelum amandemen. Sejatinya, kewenangan legislasi pasca amandemen UUD 1945 dominan berada di tangan DPR. Namun demikian, Presiden dan DPD tetap diberikan kewenangan dalam pembentukan undang-undang. Pasca amandemen UUD 1945 terlihat adanya pergeseran kekuasaan legislasi dari Presiden ke DPR. Menguatnya kewenangan legislasi yang ada pada DPR sebagai lembaga legislatif ternyata tidak dapat membuktikan bahwa regulasi yang dihasilkan menjadi sepadan dengan meningkatnya kewenangan yang didapatkan pasca amandemen ini. Pada kenyataannya, regulasi asal Presiden dan DPD sebagai lembaga eksekutif terlihat lebih aktif dalam legislasi dibandingkan regulasi yang berasal dari DPR.

\section{Daftar Pustaka}

A. Buku

Jimly Asshiddiqie, 2006, Perkembangan dan Konsolidasi Lembaga Negara Pasca Reformasi, Jakarta: Sekretariat Jenderal dan Kepaniteraan Mahkamah Konstitusi Republik Indonesia. Jimly Asshiddiqie, 2014, Pengantar Ilmu Hukum Tata Negara, Jakarta: Rajawali Pers, Jimly sshiddiqie, 2014, Pengantar Ilmu Hukum Tata Negara, Jakarta: Rajawali Pers, Jimly Asshiddiqie, 2006, Perkembangan dan Konsolidasi Lembaga Negara Pasca Reformasi, Jakarta: Sekretariat Jenderal dan Kepaniteraan Mahkamah Konstitusi Republik Indonesia.

B. Jurnal

Affandi, Hernadi. "Problematika Fungsi Legislasi Dewan Perwakilan Daerah Dalam Hegemoni Dewan Perwakilan Rakyat." PADJADJARAN Jurnal Ilmu Hukum (Journal of Law) 1, no. 1, 2014: 135-54. https://doi.org/10.22304/pjih.v1n1.a8.

Airlangga, Shandi Patria. "Hakikat Penguasa Dalam Negara Hukum Demokratis." Cepalo 3, no. 1, 2019: 1-10. https://doi.org/10.25041/cepalo.v3no1.1783.

Aritonang, D. "Penerapan Sistem Presidensil Di Indonesia Pasca Amandemen UUD 1945." Mimbar Hukum - Fakultas Hukum Universitas Gadjah Mada 22, no. 2, 2010: 391-407. https://doi.org/10.20303/jmh.v22i2.296.

Hadi, Syofyan. "Fungsi Legislasi Dalam Sistem Pemerintahan Presidensil (Studi Perbandingan Indonesia Dan Amerika Serikat)." DiH: Jurnal Ilmu Hukum 9, no. 18, 2013. https://doi.org/10.30996/dih.v9i18.275.

Herman, Herman, and Firman Muin. "Sistematisasi Jenis Dan Hierarki Peraturan PerundangUndangan Di Indonesia." Jurnal Komunikasi Hukum (JKH) 4, no. 2, 2018: 89-101. https://doi.org/10.23887/jkh.v4i2.15445.

Hood Phillips, Paul Jackson, and Patricia leopold, 2001, Constitutional and Administrative Law, London: Sweet \& Maxwell,

Isra, Saldi. "Hubungan Presiden Dan DPR.” Jurnal Konstitusi 10, no. 3, 2013: 399-416.

Marlina, Rika. "Summary For Policymakers." In Climate Change 2013 - The Physical Science Basis, edited by Intergovernmental Panel on Climate Change, 1:1-30. Cambridge: Cambridge University Press, 2018. https://doi.org/10.1017/CBO9781107415324.004.

\footnotetext{
31 Shandi Patria Airlangga, "Hakikat Penguasa Dalam Negara Hukum Demokratis," Cepalo 3, no. 1 (2019): 1-10, https://doi.org/10.25041/cepalo.v3no1.1783.
} 
Mawarini Sukmariningsih, Retno. "Penataan Lembaga Negara Mandiri Dalam Struktur Ketatanegaraan Indonesia." Mimbar Hukum - Fakultas Hukum Universitas Gadjah Mada 26, no. 2, 2014: 194-204. https://doi.org/10.22146/jmh.16039.

Pigome, Martha. "Implementasi Prinsip Demokrasi Dan Nomokrasi Dalam Struktur Ketatanegaraan Ri Pasca Amandemen Uud 1945." Jurnal Dinamika Hukum 11, no. 2, 2011 : 335-48. https://doi.org/10.20884/1.jdh.2011.11.2.191.

Pirmansyah, Miki. "Eksistensi Dewan Perwakilan Daerah Dalam Sistem Bikameral Di Indonesia." JURNAL CITA HUKUM 2, no. 1, 2014. https://doi.org/10.15408/jch.v1i1.1461.

Puspitasari, Sri Hastuti. "Penyelesaian Sengketa Kewenangan Konstitusional Lembaga Negara Sebagai Salah Satu Kewenangan Mahkamah Konstitusi." JURNAL HUKUM IUS QUIA IUSTUM 21, no. 3, 2014: 402-25. https://doi.org/10.20885/iustum.vol21.iss3.art4.

Riswanto, Agus. "Strategi Politik-Hukum Meningkatkan Kualitas Kinerja DPR Ri Dalam Produktivitas Legislasi Nasional." JURNAL CITA HUKUM 4, no. 2, 2016. https://doi.org/10.15408/jch.v4i2.4140.

Saldi Isra, 2010, Pergeseran Fungsi Legislasi: Menguatnya Model Legislasi Parlementer dalam Sistem Presidensial Indonesia, Cet. 1, Jakarta: PT. Rajagrafindo Persada.

Solihah, Ratnia, and Siti Witianti. "Pelaksanaan Fungsi Legislasi Dewan Perwakilan Rakyat Pasca Pemilu 2014: Permasalahan Dan Upaya Mengatasinya." CosmoGov 2, no. 2, 2016 : 291. https://doi.org/10.24198/cosmogov.v2i2.10010.

Supriadi, Yadi. "Komunikasi Politik DPRD Dalam Meningkatkan Peran Legislasi Di Kota Bandung." Mediator: Jurnal Komunikasi 10, no. 1, 2017: 25-36. https://doi.org/10.29313/mediator.v10i1.2119.

Yulistyowati, Efi, Endah Pujiastuti, and Tri Mulyani. "Penerapan Konsep Trias Politica Dalam Sistem Pemerintahan Republik Indonesia: Studi Komparatif Atas Undang-Undang Dasar Tahun 1945 Sebelum Dan Sesudah Amandemen.” Jurnal Dinamika Sosial Budaya 18, no. 2, 2017: 328-38. https://doi.org/10.26623/jdsb.v18i2.580.

Zulfan, Zulfan. "Analisis Pengaturan Dan Praktik Pemisahan Kekuasaan Sistem Pemerintahan Presidensial Berdasarkan Konstitusi." Jurnal Media Hukum 25, no. 1, 2018: 60-67. https://doi.org/10.18196/jmh.2018.0102.60-67. 